\title{
How the Coronavirus Pandemic Will Change Our Future Teaching
}

Higher education has experienced pandemics and economic downturns over its long history. Recent events have invited comparisons to small pox scares, worldwide flu epidemics, and other moments of fear for student, faculty, and staff health. Campus leaders are nervously watching the bottom line while students and parents worry and contemplate different modes of learning, deciding whether they want to buy what colleges and universities can offer. Faculty, meanwhile, forged new sorts of relationships with their students during spring semester 2020 and wonder about how this environment might continue going forward.

Among many in higher education, there is a sense that something has forever changed. For over a decade, we have talked about the differences between face-to-face and remote classes, debating their relative pedagogical and financial merits. With recent events blurring all forms of instruction into virtual classrooms and online assignments, Facebook pages and websites sprung up for faculty to share ideas, teaching modules, and assignments. Social distancing has, ironically, added a new appreciation for the larger learning community, reminding us of the value of quality online materials and revealing again that good teaching is as collaborative as good research.

Having learned new things about teaching and learning, how will this experience be built into our courses going forward? In other words, how has the pandemic affected how we will teach in the future? What has forever changed?

As a regular feature of Religion and American Culture, the editors invite scholars to comment from different perspectives upon an issue or a problem central to the study of religion in its American context. This FORUM format is designed to foster the cross-disciplinary study of religion and American culture and to bring to the readers of the journal the latest thoughts of scholars on timely, substantial topics. Contributors to the FORUM are asked to present brief essays or "thought pieces" instead of carefully documented articles.

Religion and American Culture: A Journal of Interpretation, Vol. 30, Issue 2, pp. 147-186, ISSN: 1052-1151, electronic ISSN: 1533-8568. () 2020 by The Center for the Study of Religion and American Culture. All rights reserved. Please direct all requests for permission to photocopy or reproduce article content through the Cambridge University Press's Reprints and Permissions web page, https://www.cambridge.org/about-us/rights-permissions. DOI: https://doi.org/ 10.1017/rac.2020.10. 


\section{Rebecca Barrett-Fox}

Almost immediately after the widespread closures of college campuses in mid-March 2020 in an effort to slow the spread of the coronavirus, assurances that all would be back to normal as soon as possible began to circulate. We will be okay, we told ourselves. Higher ed has survived crises before. Institutions rarely fail. We submitted our Fall 2020 book orders and looked forward to a return to campus. The promise of fall-reading the library books we forgot in our offices in our hurry to leave, greeting fresh-faced students-urged us forward, helping us manage what felt like the impossibility of pivoting quickly to remote teaching and our sadness at saying goodbye to our face-to-face classes.

The anticipation of a return to normal was a coping mechanism, a form of denial that helped us delay our grief and anger at injustice in higher education that the coronavirus pandemic was exposing so that we could slog through the remainder of the semester. This hope, though, was also an expression of survival bias: not all of us will be okay. Not all of us-faculty, students, institutions-will survive. Optimism for a relatively fast recovery helped carry some of us through some difficult weeks. Others of us literally died or were swept under by ill health or family obligations. Others of us will see our careers derailed by gaps in our CV created by childcare and eldercare, work disproportionately borne by women. As long as this optimism distracts us from the unequal risks of death, injury, and harm created by the pandemic-including health, economic, social, and political harms-then it wicks energy from the transformative work that universities could be doing even, and perhaps especially, now.

Already, we are being asked to teach in pursuit of homeostasis-to preserve the old relationships among students, educators, administrators, board members, donors, taxpayers, state politicians, and the "public-private" investors who increasingly influence higher education. The pattern we were in was predictable, but, for many of us, homeostasis was an entire career length of decreasing funding from states and increasing costs to students, cuts to the humanities, and mistreatment of the precarious laborers who do the bulk of the teaching at universities. Indeed, these are some of the reasons why a virus has become a disaster for higher education.

Despite fostering some of the world's best thinkers on topics of pandemics, U.S. universities were broadly ill-prepared, without sufficient training or support for faculty to successfully teach remotely or, perhaps more damningly, a plan for economic survival if campuses could not physically reopen for a single semester. 
Assurances that campuses would return to normal was as much an expression of denial as it was an avoidance of reality: too many campuses, including those with the endowments larger than the GDP of small nations, showed themselves to be financially unprepared for a major dip in tuition, having chosen expansive and risky spending on real estate, international campuses, ballooning coaching and administrative salaries that mimicked income inequality in business, and other ventures that created thin margins for them. Their financial expenditures did not always narrowly support student learning, but they were incredibly student-centered in terms of where their money came from. In 2019, according to the State Higher Education Executive Officers Association's most recent State Higher Education Finance report, 46 percent of revenue was from students; the organization predicts that will surpass 50 percent during the coming recession. The tension, of course, is that higher costs to students and lowered state support may still result in fewer opportunities for students, including fewer connections to faculty in long-term jobs, even as they pay more for and see a lessened financial return on their investment if they graduate into an economic depression. As frightening as this prospect is, it only follows a long-term trend; nationally, appropriations for higher education have remained below pre-Great Recession levels even as those who have graduated since 2008 launched into precarious jobs.

Many of us simply are unable to muster nostalgia about a prepandemic university, given that we never participated in it as respected, adequately remunerated campus citizens and, as things were going, never were going to. We are obligated, I think, and also motivated to teach against a return to normal and for a turn toward justice. This means silencing our own internal voices that assure us that everything will be okay and, instead, raising our voices to demand that universities eliminate the inequality that has led to coronavirus's disproportionate harm to people of color, women, people living in or near poverty, and those with disabilities on campuses. It means rejecting comforting appeals to a past in which the academy was a respected, supportive meritocracy-which, for the roughly three-quarters of college educators who are not on the tenure track, has never been part of our experience-and creating institutions that model and foster the kind of interactions necessary for the welfare of democracy and the demos that compose it. This requires us to reject superficial calls for a return to normality and do deeper, harder, and more honest work.

Religious studies scholars have unique insights and skills to do this work in their classrooms and as part of the larger university. Scholars of religion are critical thinkers, able to read texts carefully, 
synthesize and analyze information, suss out inconsistencies, discern patterns, and weigh interests. We, too, though, must resist the temptation ever to call our efforts enough; all progress must be guarded not only from attacks from the powers that benefit from neoliberalism in higher education but from our own self-satisfaction. In the remainder of this essay, I focus on three temptations that I face (you may face your own!) in this fight for a better postpandemic university.

\section{Charity versus Justice}

Charity, from the Latin caritas, comes from our hearts. It is freely given, gratuitous, and undeserved. Indeed, if it is deserved, then it is not charity but simply the repayment for a debt, a transaction between two people who were able equally to enter a contract in which they exchanged things they considered to be of relatively similar value. Charity, in contrast, is a gift given with no expectation of reciprocation, though those who give charity may experience altruism, public praise, an increase in the esteem of others, or (even if they do not admit it) superiority, which may be their own rewards.

In teaching, charity is tempting. College educators, by definition, have power over students. We can dispense and withhold charity as we like, which means that, if we are not committed to antioppression pedagogies and practices, we will, by default, at least sometimes, allocate it according to internal biases. We will decide that a student who is a father gets an extension on his work because his child's daycare is closed in response to the pandemic but that a mother should have had a backup plan for childcare; he receives charity, and she does not. We will decide that the COVID-caused death of a parent is worthy of an Incomplete but that the COVID-related death of an ex-step-parent is not; students from families that do not adhere to the nuclear model are, thus, denied charity while those whose families are already likely to be more respected receive it. Because Black, Hispanic, and indigenous communities have higher rates of coronavirus infection and COVID-related deaths, sexism and classism in the dispensation of charity around the pandemic is also likely to be racist (and, because poor students are more likely to be students of color, racism, in its dispensation, is likely to be classist). Additionally, because some students are better at identifying what they need, who can give it to them, and how to advocate for it, those students are more likely to request charity (or to demand it, perhaps, with the implication that, if it is not granted, we will be hearing from their father the donor). When people's needs are met through charity, not through justice, then those 
who are least likely to ask for charity-that is, those who are taking the most responsibility for their inability to meet expectations-are disadvantaged; in contrast, those most likely to ask for charity are those most experienced at getting it. The Matthew Effect-in which the rich get richer and poor get poorer-results in those privileged enough to have received charity in the past asking for more and those who have been taught not to expect it not asking at all.

But charity feels good! We enjoy the gratitude of students who need us to save them. (And, perhaps, we sometimes enjoy judging students whose pleas for charity do not meet our standard for giving it.) We are rewarded, moreover, for charity. Applications for teaching awards, for example, often invite students to provide examples of charity, stories of a time when a faculty member "went the extra mile" (a performance of underserved kindness, expressed in a metaphor from Christianity). These good feelings make charity a temptation.

Justice, in contrast, often feels bad. It requires confronting oppressive systems (hard, painful, often unrewarding) rather than giving gifts to individuals (fun, may create a sense of obligation in the person that you can later exploit). It requires admitting to your own power within a system (you are not helpless to effect change, even if you keep telling those with less power that your hands are tied). The pursuit of justice requires you to challenge those with more power than you when you would rather exert benevolent power over someone with less of it. Justice requires bringing people without power into power, whereas charity reaffirms the distance between those with less and more power. College educators often feel caught between powerlessness and power. Entrusted with shaping the minds of the future of the nation, most of us are also told that our services could be dismissed without cause. In this uneasy place, charity reminds us that we do have power and that enacting it can make a positive impact on the lives of individual students. During a pandemic, it is especially tempting, because we know that students are actually suffering. Yet, even now, charity is a poor replacement for justice.

During and after the coronavirus pandemic, justice in teaching might look like challenging grading systems that measure student resources to learn during a crisis (such as access to a quiet space to attend your synchronous Zoom lectures) rather than student learning. It might mean automatic extensions of funding for graduate students who are parents and must teach their own children at home while also being students. It might mean lowering the cost of tuition for some classes so that students can retain their full-time status and avoid triggering mandatory loan repayment. Especially since the economic turmoil from the pandemic is likely to 
last longer than the health threat, justice includes student loan forgiveness and free tuition, fees, and room and board at public universities.

Justice is harder to achieve than charity, and, perhaps, readers are now wondering if I am being reasonable, since teachers cannot create justice by themselves. But teachers are part of departments that decide how graduate students are funded, colleges that decide the fee structures for courses, and an electorate that chooses to charge interest for learning. Teachers can, at minimum, increase justice in their own teaching practices. You will know you are successful at increasing justice when requests for charity decrease; when everyone has access to what they need to be successful, fewer people will individually petition for it.

\section{Unity versus Solidarity}

Calls for a return to normal often request unity. (Take a moment to search your email for the number of times the word has appeared in pandemic-related emails from your chancellor. To date, it has appeared in nearly every email sent by a higher administrator on my campus.) Unity demands that members focus attention on shared goals-which means ignoring difference and hushing critique. Unity requires a prioritization of common goals, even if they are not the most important or urgent needs of individuals or groups, and, thus, it often results in selecting goals that are least meaningful to those most marginalized and most important to those who already have the most power. Consequently, unity delays solutions to problems that may be deep and important but affect those who have less power to set priorities. For example, in the effort to prepare for Fall 2020, I witnessed one university chancellor reject the idea that perspectives from people with disabilities or people from racial and ethnic groups disproportionately dying of COVID should be specifically considered because not "every single group... need to be represented" in pandemic planning. This was a call for unity, with its attendant silencing of complaints by groups whose needs were being ignored, in order to produce a "common good" that served the needs of the majority of people, not those who had the most or most urgent needs. In this case, the same administrator publicly announced that the common good around which faculty and students would rally was the preservation of "our academic environment, the intellectual advancement of our students, and all that [this university's] experience promises"-which could only be met through a reopening of the physical campus. When those most threatened by prioritizing a physical return to campus criticize that 
decision, they threaten the façade of unity. One faculty member shared with me that she was scolded by her dean for critiquing her university's lack of support for online teaching during this time. "Whose team are you on?" she was asked. If a campus is, indeed, unified, then there are no "teams." That the question was raised reveals the way that unity is manufactured to paper over divisions, including ones that, if they were explored, could result in better decision-making. Unity gives the false impression of consensus when it is, instead, an effort to subjugate and erase dissent. Consensus, or the appearance of consensus, makes us more, not less, vulnerable to a virus if what we agree on is inaccurate, false, dangerous, or misguided.

Despite the practical problems that result from consensus created through roughshod means, unity is tempting, and it can creep into our teaching, too. As educators, we often deliberately foster a sense of unity, especially among students in the same major, academic cohort, academic honor club, or student group. In the classroom, we may invoke a sense of unity to encourage students to overcome a challenge ("We're all reading this hard text together!") or collaborate, but the drive for unity can, even if inadvertently, teach students that they contribute through compliance rather than dissent and that having unique needs met is theft from the group. We do this when we craft policies that we anticipate will work for most students (or students with the most power) and ask other students to sacrifice to comply with them. We do it when we create assignments that benefit some students but not others and ask all students to complete them, regardless of the value of them to their own learning. Perhaps, most damagingly, we do it when we ask students who are harmed by hateful speech and arguments to endure a classmate playing "devil's advocate" or performing a "thought experiment" or ask them to denounce positions they do not hold ("Yes, Muslim terrorism is bad") in order to preserve the unity of a classroom. When we encourage people who have been historically oppressed to sit in silence in the face of arguments that injure or disrespect them or their ancestors in order not to disrupt our "academic environment," we are promoting unity over solidarity.

Solidarity is a threat to unity because solidarity is a call to identify with the needs of the most vulnerable, including vulnerable faculty and staff, not with the desires of those with enough power to set group priorities. A pedagogy of solidarity adheres to a kind of academic preferential option for the poor: always addressing first the needs of the most vulnerable students. During a pandemic, this means choosing classrooms (physical, digital, hybrid, Hy Flex), course design and policies, and assignments that are responsive to the needs of the most vulnerable students, not the most vocal 
students. Solidarity will continue to prioritize the needs of students whose lives have been upended by the coronavirus through loss of family members, economic devastation, and medical PTSD and lifelong disability from infection for those who survive it. Solidarity means providing time and space for grief, supporting students who repeatedly leave and reenter college, lowering the cost of learning for those whose families cannot afford to invest in education, and making physical campuses and online classrooms accessible to those with new disabilities. You will know that you are achieving solidarity when students begin forwarding the interests of others even when doing so diminishes the chances of outcomes that best serve their personal interests.

\section{Restoration versus Transformation}

The siren of unity entices us into thinking we want a return to what we had-a restoration of what was. Yet, what we had was not functional for many students. More than one out of three undergraduate students who begin a degree do not finish it at their original university within six years according to the April 2020 data on college retention and graduation rates from the National Center for Education Statistics. These students, though, still leave with a significant share of the nation's \$1.6 trillion in student loan debt. Those who leave without graduating often owe relatively little compared with their peers who graduate, but they are significantly more likely to default on loans. Most distressingly, students from poorer families and those who are Black and Latino are far less likely to enroll in or graduate from college, as reported in the Urban Institute's 2020 report "Understanding Equity Gaps in College Education." Even as patterns in inequity across categories of race, ethnicity, and class contributed to rising debt for those least able to afford it, college educators have typically not directly benefited from the rising costs of tuition. While some tuition money is used for services that support student learning, such as disability services centers, adjunctification and rising tuition track together tightly. In short, the people most involved in student learning-students and teachers-both paid a lot to maintain the university as it was. The coronavirus pandemic presents us with an opportunity to reevaluate if we even want to restore that.

Some students, of course, will not have a choice. The coronavirus crisis demands that they shift their priorities to teaching their own children at home or providing all their own childcare for children too young for school. They are caring for ailing parents or partners. They are working mandatory overtime at essential jobs, or 
they are searching for more work to compensate for falling wages, furloughs, and cuts to their benefits, including healthcare. They are surviving — or they are not-but they are doing it apart from college. Typically, enrolling in college during an economic downturn is a wise choice, as college may provide students with training to make them more competitive in a tough job market. Instead, the higher education research firm SimpsonScarborough's survey findings, released in April 2020, indicate a possible 20 percent drop for fall 2020 enrollment, with Black and Latino students reporting far less confidence in attendance than their white peers. Overall, about half of students reported COVID-related disruptions to their family's finances-numbers only likely to increase as students who previously relied on summer work to pay for college find their jobs gone.

Restoration, in short, may be neither desirable nor possible. Even so, it is beguiling. In my conversations with a wide swath of college educators this spring and early summer, many hope to return to on-campus teaching, for a variety of positive reasons: it affirms their identity, allows them to teach in a way that they best know how to do, and is typically more satisfying for students who choose face-to-face learning. These are good reasons to want to meet again in person soon. The challenge is to restore these parts of the learning environment-when it is safe to do so-without resurrecting patterns that contributed to inequality among students and precarity for so many educators.

The university is transforming, and, indeed, the speed at which it is doing so-financial cuts in the millions at some universities, enacted within weeks of the start of the pandemic, with more coming as state tax revenues fall-is frightening for some and frustrating for others. For many of us, universities that have demanded patience with their inertia around issues of accessibility, inclusion, and social justice have promised impossible nimbleness in creating a "socially distant" campus. Somehow, universities without funds or ambition to create genuinely accessible campuses-ones that go beyond the requirements of the ADA to ensure full inclusion of all students in every area of campus life-now promise to run classes at a fraction of their size, with faculty and students separated by plastic barriers and daily COVID testing. These changes, while large and costly, are efforts to restore campus to something like what it was for those students who can access it: those with the funds during an economic crisis to pay for it, the child and eldercare to provide time for it, and the physical bodies more likely to survive an infection. They are not transformations of campus into a more inclusive place, one where more knowledge is generated because more people and 
more kinds of people participate in the work of learning and teaching and researching; they are expensive efforts to prop up an ever-more-exclusive endeavor.

For a college education to be an education, rather than just a credentialing source, it must be transformative. Institutions that, in the face of a threat the scale of the coronavirus pandemic, react by pining for a past that never was (and, to the extent that it was, was exclusionary) or consolidating old power differentials will struggle to foster transformative learning, at least for the groups that most need it: those most likely to be harmed by the coronavirus pandemic who need evidence that their own learning can shape their individual lives and collective experiences, and those most secure in the face of the pandemic who need to be challenged to investigate critically the sources of their security. Transformative teaching includes identifying the real, specific needs and motivations of students and channeling them into meaningful challenges. It includes exposing students to perspectives they had not previously considered and helping them to see, as much as they can, from them, helping them articulate positions they had not previously considered and evaluating evidence they could not find on their own. Transformative teaching is sometimes affirming, but it is mostly disorienting. You know you are succeeding at it when students begin to approach the classroom with questions, curiosity, and humility rather than theses and arguments. You know you are succeeding when students pursue transformation after the semester ends rather than restoration of the ideas with which they entered the course.

I understand the argument that a time of medical crisis, economic disaster, and social suffering is not the time to ponder a new university. Changes to how we individually teach, changes to our universities, and changes to our higher education system, from funding to the laws that govern it, require time, energy, and resources we may not feel we have right now. A return to homeostasis might not be the long-term best choice, but it is the easiest choice right now, and we all deserve a little ease after spring 2020.

I think, though, that the investment in significant changes in teaching, even now, when they are hard to make, are worthwhile for very practical reasons. Indeed, I think they may be the only thing that can save a higher education system that has long been threatened. Here is why.

The university as we knew it was already diminishing. Enrollments were down-which is less, to me, a concern about the financial viability of colleges and more a concern about the vibrancy and durability of our democracy. Attacks on higher education from 
multiple angles were waged not just by conservatives who depicted universities as liberal bubbles hostile to their political ideas but also by moderate and liberal politicians who prioritized "readiness to work," rather than participation as a global citizen in the work of democracy, as the end goal of education. A slowing birth rate among the middle and upper class combined with rising college costs that have kept poor and working people from access to education have contributed to falling enrollments. The percent of students enrolling has declined each of the last ten years according to the National Student Clearinghouse Research Center's spring 2020 current term enrollment estimates. Very simply, even before the current pandemic, universities' old ways were not working, not only for so many students and faculty but also for the universities themselves.

Optimism, individual acts of kindness toward students, calls for unity, and the preservation of tradition have not worked to keep campuses safe from the damage of the global pandemic; to the extent that they competed with justice, solidarity, and transformation, they contributed to vulnerability. Perhaps campuses can never be pandemic-proof; they exist in broader systems (and cities), after all, and germs spread among students who enroll to party as well as those who enroll to change the world, among racist faculty and antiracist ones. But universities can be leaders in modeling behaviors and policies that reduce the havoc that a pandemic wreaks. Justice, solidarity, and a commitment to transformation mitigate the harms of all kinds of disasters. We build a better and more resilient university when we embrace them.

Rebecca Barrett-Fox is Assistant Professor of Sociology at Arkansas State University.

\section{Brandon Bayne}

It is a strange feeling going viral because of a virus. Viral is a relative term here. We are talking about thousands, not millions, at the scale of academics, not athletics. Still, something that I wrote traveled a bit for a few weeks this past spring, making its way around social media, pedagogy groups, teaching centers, sample syllabi, Zoom webinars, and even a few university strategic plans. The Chronicle of Higher Education did a little write-up (Beckie Supiano, "'Nobody Signed Up for This': One Professor's Guidelines for an Interrupted Semester," Chronicle of Higher Education, March 20, 2020, https://www.chronicle.com/article/Nobody-Signed-Up-for/248298), 
a few reporters and podcasters came calling, somebody turned it into a YouTube video, and, ultimately, Time magazine featured the piece and a bit of the backstory to my attempt to grapple with the most challenging of semesters (Megan McCluskey, "Nobody Signed Up for This': College Professor Drastically Rethinks Syllabus to Prioritize Human Need Amid Coronavirus," Time, March 27, 2020, https:// time.com/5810736/college-syllabus-coronavirus/).

I was getting hundreds of emails there for a while, first from fellow scholars of religion and then from professors of chemistry or communication or clarinet. Somehow, my principles for an adjusted semester made their way to school teachers, too, and I began to hear from high school algebra instructors, seventh grade special needs aids, and third grade literacy specialists. My daughter's kindergarten teacher texted me about it. She said the principles had made the rounds among the faculty and staff at my kids' elementary school, and they were adapting it in various ways. Eventually, somebody translated them to Spanish and then to French, Portuguese, and Mandarin. For a minute, there, I could track in real time as teachers in different parts of the globe began to grapple with the same decisions we had found ourselves making in North America and wrote me or accessed the Google Doc I had shared. Learning that those words were helping some find space to make tough decisions and move forward humbled and encouraged me in the midst of an otherwise terrible time.

Eventually, it all slowed down, and I heard less from folks, and the requests to use the principles trickled down to a few a week, and, with that, my fifteen minutes of nerd fame came to its predictable denouement. Meanwhile, I had to get to teaching and try to implement those impossibly idealistic aspirations. That was the tougher part, but, by late May, I was wrapping up the semester and beginning to forget about the whole episode until I was asked to contribute something to this forum on how the coronavirus pandemic will change our future teaching. Currently, I am facing a fall semester in which my university has mandated that I must teach face to face with the ability to be "hybrid" and "hyflex," prepared to teach both synchronously and asynchronously, in person and from home, and always ready to take it all online at a moment's notice.

So, here we are, once again contemplating what principles we need to hold in mind as we make new decisions about learning objectives, assignments, discussion techniques, and how we do all of that while hoping we do not contract or spread a deadly virus. From those ideas-that nobody signed up for this, that the humane option is the best option, that we cannot just do the same thing online, that we must foster intellectual nourishment, social connection, and 
personal accommodation, and that we should be flexible and ready to adjust to an ever-changing situation-we must determine which remain relevant and which were merely helpful for a moment of transition. My mini-viral moment is long gone, but this momentous virus marches on, and we are all once again left to figure out how we must adapt ourselves and not lose our way in these ongoing, seemingly interminable, "trying times."

\section{"Nobody Signed Up for This"}

The principles were written in twenty minutes, jotted down on the proverbial napkin as my first thoughts after reading the results of a poll that I had sent out to my students. I asked them basic things, modeled on the five W's (who, what, when, where, why) that I emphasize constantly in every introductory course. "Where are you? Who is with you? What time zone is it? What technology/resources do you have? How are you feeling and why?" The pie graphs and charts that came back from it told me that we would not be able to simply "do our classes just as promised in the beginning of the semester, but online," as our administration had instructed us. Students were living in a wide range of contexts, with variable access to resources, and experiencing wildly diverging sentiments from anxious boredom to debilitating panic. In light of those responses, I had to figure out what changes to make in our plan and what we all needed to hold foremost in mind as we made them. What was entirely clear at that moment is that none of us were ready in any way for what was ahead.

I know I was not ready. I was visiting my father when we received the news. Like many of us, my university announced that it would be extending Spring Break for a week, while instructors would work to transition their courses online for the remainder of the semester. At first, I was personally thankful for the respite because I was not prepared to return. It was the end of a difficult week at the end of a difficult month and still at the beginning of the most difficult of years. I had returned home to help my father as he transitioned to life as a recent widower, still reckoning with the loss of my mother, who passed away in January from an aggressive cancer. I had been back and forth several times already, working to take care of her as she began chemotherapy and radiation treatment, but then having to quickly adapt as she realized her end was coming faster than any of us had imagined. She told me on a Wednesday morning after my father left for work, just as I was sitting down for a bowl of Quaker oats with blueberries. "I'm not going in for radiation. I am done, and I am at peace." 
When I told my students that "nobody signed up for this," it was about more than the pandemic. It was about life, this shared experience where sudden turns can blind you, spin you around, and leave you swinging aimlessly to the tune Mexican children sing when they search for an elusive piñata:

Dale, dale, dale,

No pierdas el tino;

Porque si lo pierdes

Pierdes el camino.

“Go, go, go, but don't lose your sense, because if you lose it, you'll lose your way." I was just trying to keep going, to not lose my senses, to hit on something, so as not to lose my way.

In that moment of transition, it just felt like it needed to be acknowledged that nothing was normal. Even normal is not normal but is, instead, the imposition of order on an inherently unpredictable existence. Yet, we take comfort in normality, in the ongoing regularities that give us relative security. Nothing could be worse than to surrender to uncertainty, to fragility. As our normal was stripped so suddenly away, nobody was ready for it. We were all scrambling for sense, searching for a colorful paper burro that none of us could find, a novel virus with no treatment, a social pandemic for which nobody, certainly not our national leadership, had planned. We were not ready for any of it. Not the sickness, not the new language and practice of "social distancing," not the sudden end of our collective lives together on campus. We were equally unprepared to teach and take online classes, and we all felt awkward about that forced and sudden rush to master new technologies that also entailed exposing the sacred space of our homes, the very sanctuaries we had cultivated as refuges from life's chaos. Our deans told us to make up the lost hours, to stick to the plan, to satisfy onlooking accreditors. There we were, trying to remake everything that had been upended and reimpose a sense of order on the fragility of life, "Dale, Dale, Dale," keep going lest we lose our sense and ultimately our way.

\section{"The Humane Option"}

I was far from home when I found out my mom had cancer. It was just after New Year's Day, and I was in New York City at the annual meetings of the American Historical Association/ American Society of Church History/American Catholic Historical Association/Conference on Latin American History (yes, my strange 
little research niche means that I attend them all). I was headed to a roundtable for the ACHA on teaching U.S. Catholic history when my sister called. "Has dad called you? It's worse than we thought." Just tell me, I urged her. "It's everywhere, she's in tremendous pain, and she can't breathe." I held the phone away from my face, and the elevator rose as my stomach sank. Stepping out, "I'll call you back. I have to do a presentation." I got through it, mumbling something about treating each student with an eye toward our shared humanity and tailoring our classes to personal situations. Then, I scrambled out. Running back to my hotel room, I pulled out the phone to check my texts, and I realized that I had lost my wallet. So, I hustled back to the Sheraton and retraced my steps all the way to the very same elevator where I had received the news, just hours before. The doors opened and I stepped back in, only to greet a hotel concierge who turned to me and asked, "Are you Brandon?" Relieved to reunite with my driver's license and credit card, I marveled that, because of the finder's goodwill and a random encounter with the concierge on the fated elevator, I could get a flight and get home. For a moment, I indulged the magical thought that it might be a sign that my mother would be all right.

The spring 2020 version of the University of North Carolina's "RELI 140: Religion in America" kicked off two days later. That was a Wednesday, but, by the end of class on the following Monday, I had to tell this new batch of 120 students, who had known me for less than a week, that I needed to leave. I had to go home to take care of a family emergency. "Please be flexible with me," I asked of them, and "we will work to communicate clearly, keep the class on track, and take care of each other." As I flew to Oklahoma to be with my mother, I had to lean on excellent graduate student teaching assistants and fellow faculty to step in and help. I asked them all-the students, my TAs, my colleagues - to see me as human, remain flexible, and work with me as I found my way. So, from the beginning of the semester, I had needed to prioritize the most important people in my life, and I was going to need everyone else's support to pull through and keep going. More than ever, we would have to admit to our humanity, submit to life's fragility, and do our best to find simple solutions and shared resources to pull ourselves along.

\section{"Not the Same Online"}

When it finally was clear that we would need to transition online, it became painfully obvious that we could not just do the same thing. Some assignments were no longer possible. Some expectations were no longer reasonable. Some objectives were no 
longer valuable. Before the break, I had told them to use it as a time to think about their "Field Experience Papers." They were each tasked with identifying a religious group outside of their own tradition, researching its history, contacting a local congregation, and, ultimately, visiting to do "mini-ethnographies" that reflect on the group's social location as well as the student's own positionality. When I sorted through their responses to my poll, however, I realized right away that the field experience paper could not happen, at least not in the same way. Even before our governor began to limit meetings, I knew that we could not send our students out to visit diverse religious gatherings throughout North Carolina and beyond without putting them and those congregations in danger. Then, I began to think of other assignments we had planned. We had two more "Ready Reactions," or brief in-class pop quizzes, meant to test preparation and attendance. If we were not meeting in person, that seemed impossible or, at the very least, impractical. And what about that final exam, full of fifty short identification questions and two short essays? Could we do that online, and, if so, what sort of surveillance would we need to employ to guard against cheating or plagiarism? It now felt unreasonable and much less valuable than I had always believed.

In the month after my mother's sudden diagnosis and precipitous decline, I read a short blog post that had been on my mind for weeks. It was like another round with the piñata, where it had spun me around and left me swinging for a better approach to life and teaching. It was called "Against Cop Shit." The author, Jeffrey Moro, is a PhD student at the University of Maryland, and he forwarded a simple thesis: "Abolish cop shit in the classroom." Moro went on to define this as "any pedagogical technique or technology that presumes an adversarial relationship between students and teachers." For example, he pointed to the tracking of students' movements, software to detect plagiarism, overly strict attendance policies, and the celebration of "grit" and "discipline" in the interest of enforcing conformity to our syllabi and class policies. From the second I read it, the phrase had stuck with me. "You are not a cop, so why are you doing cop shit?" (Jeffrey Moro Blog, February 13, 2020, accessed June 13, 2020, from https://jeffreymoro.com/blog/ 2020-02-13-against-cop-shit/)

\section{"Fostering Nourishment and Connection"}

As I write these reflections in early June 2020, that refrain seems more important than ever. Collectively, we are asking ourselves the question of how our teaching needs to change in the 
face of not just one pandemic but also two simultaneous and interrelated crucibles. At this moment, the coronavirus pandemic has us mostly at home, in front of our screens, and relatively undistracted by school or sports or the impending election. We are attuned in an unprecedented way, and we have just a bit of extra time and increased attention. When those horrific videos of Ahmaud Arbery and George Floyd being murdered began to go viral in their own way, we could not look away as we had with Eric Garner or Philando Castile. Ahmaud was out for a run when he was gunned down by a recently retired, thirty-seven-year police veteran and his son, acting as a vigilante posse in their gated Georgia community. George had a cop kneel on his neck for eight minutes and forty-six seconds as onlookers protested and his fellow officers deflected. These brutal scenes, on top of the stories of countless othersBreonna, Tamir, Botham, Trayvon, Michael, Sandra, to name just a few-had a whole lot of us entirely sick of cop shit and realizing that we had allowed it to pervade every aspect of life.

Policing is not the same as teaching. The stakes are different, and there are good reasons to build accountability into our learning communities. Let us not be tempted, however, into thinking cop shit stops in the streets or remains confined to police departments. We have been doing a lot of policing in our classrooms, lulled into the gradual ramping up of the surveillance of our students' movements and disciplining of their deviations. Yet, what does attendance and participation look like when we all desperately need each other to stay away because we are sick or socially distant when things are dangerous? If we cannot do everything the same as we had promised, maybe we should also consider what it is we have been promising that we never should have done. How can we avoid the sorts of practices that perpetuate an adversarial relationship between ourselves and our students, and why are we doing this in the first place? Dispensing with unsafe assignments (in the case of the field experience paper), unreasonable practices (in the case of the pop quizzes), and unworkable assessments (in the case of a content-oriented final exam) left quite a void for the rest of the semester. In a class that I measure on a 1000-point scale, I still had nearly 500 points for which I needed to account. Beyond the principles, I needed a pathway for the rest of the semester and for those that followed. The path I choose entails leadership rather than threat, allies instead of adversaries.

I got into this profession because it brings me intellectual nourishment, social connection, and the ability to find personal accommodations, both for myself and my students. Despite an increasingly corporate approach to learning objectives, course 
"delivery," and standardized evaluations, I still love it for the same reasons. In the face of so many surrounding pressures, I want to return to that fundamental commitment to foster nourishment, cultivate social connection, and provide individualized accommodation. One of the first things I realized after reading the poll results was that there could not be one solution. Some students were still in their dorm rooms or nearby apartments in Chapel Hill, but others were in Montana, Brazil, India, and China. Some had dedicated spaces with desks and high-speed internet. Others were sharing a room with two siblings and working from their beds. Some had their texts and notes, while others had nothing. In the ensuing debates over the virtues of asynchronous versus synchronous instruction, I felt like both would be required. Accessible asynchronous content for diverse access, time zones, and contexts, paired with optional synchronous discussion to learn together and combat isolation.

\section{"Remain Flexible and Adjust"}

I had asked students to be flexible from the beginning of the semester, and, once again, I called for a renewed adaptability as we reworked the course schedule, recorded abbreviated lectures, adjusted assignments, and set new due dates. I reminded them again that we would need to remain ready to adjust to situations as they changed. Nobody knew where it was going. We still do not. The only thing we know is that we must prepare for a reality in which we are all keenly aware that the "new normal" has reminded us of the transience of normality. This will mean mastering some new technologies and techniques. I just finished teaching an intensive summer school version of the same course, "Religion in America," in the last few weeks of May. To adjust it to a fully online environment, I had to work together with an instructional designer and a graduate student to build out self-contained "Lessons" for each day in our learning management system. They consisted of five steps: Read (a scholarly overview), Watch (an hour-long video), Analyze (an historical document), Respond (in an online Forum Post), and Discuss (in a daily synchronous gathering on Zoom or asynchronous recording/response). It was an incredible amount of work to redesign a course that I have taught dozens of times to this specific context. We dispensed with previously used books and instead identified and linked digital sources for every part of the course. We transitioned from quizzes to small group assignments on Google docs. Finally, we replaced the field experience paper and final exam with an eight-page digital E-Book that offers students the chance to 
apply all of the skills they acquired to the study of a particular local congregation, describe how they are navigating all of the challenges of our current moment, and present their findings to a four-person cohort in Zoom breakout rooms (see Jennifer Gonzalez, "Student-Made E-Books: A Beautiful Way to Demonstrate Learning," Cult of Pedagogy, September 24, 2018, accessed June 8, 2020, https:// www.cultofpedagogy.com/student-e-books/). You know what? It was a wonderful learning community, far surpassing anything I had imagined could happen online.

Beyond pedagogical dexterity, however, what we need more than anything in this strange moment is more support and understanding, not only for undergraduates but also for underpaid graduate students, contingent faculty, and overburdened staff. I was one of several faculty who dragged their feet as we transitioned to remote teaching this spring. Did I not just write in this very piece that we cannot do the same thing online and that none of us signed up for remote teaching away from our collective life on campus? Yet, here I am in June, contemplating a return to face-to-face teaching on campus in less than two months. Because I am slotted to teach smaller seminars, our administration has designated my courses to offer "high-impact" classroom instruction and "meaningful in-person experience." Oddly, I now want to tell them that the best possible way of bringing high-impact learning and meaningful personal experience this particular fall would be through well-designed fully online teaching. Seminar discussion and small-group active learning seem less appealing with masks, face shields, six feet of social distance, and the imminent threat of a deadly disease. We are, however, grappling with an inflexible system and intransigent budgetary realities, where these humane questions buckle to political pressures, and we cannot fully determine our own way unless we are granted accommodations for medical or personal reasons. Protecting myself, however, only passes along increased danger to my faculty, staff, and graduate student colleagues.

\section{Anti-syllabus}

As faculty, we are going to need to press administrators for support, to prioritize humanity, and remain flexible and allow us to adapt to this ever-changing situation, even as they demand that we serve students. In the spring, our administrators extended Pass/Fail and COVID grade options to our students but prohibited us from knowing those selections or asking students about it. This functionally meant increased labor for me and my TAs as we personally accommodated, worried about lapsed participation, and 
provided feedback to students who had already checked out. As I consider what remains from my principles for an adjusted semester and what is lacking for what is ahead, these increased demands upon our instructional labor and the intensification of a corporate culture that single-mindedly focuses on undergraduate satisfaction strike me as the dangerous side to what I wrote. Recognizing all of the budgetary, political, and demographic pressures our institutions are facing, we nevertheless must insist that we did not sign up for any of this, that the humane option is still the best option, and that we must remain committed to fostering intellectual nourishment, social connection, and personal accommodation for all faculty, staff, and graduate students.

When the principles began to get wider attention, a colleague and good friend joked that he was going to write an "Anti-syllabus," in which he would explain to students that he would not adjust a single thing. He joked that these "Bizarro World Principles" would insist that we all should have been ready for this, that the overall system must take precedence over human concerns, everything could be done online, and that increased rigor and unwavering enforcement would be essential pedagogical touchstones moving forward. Of course, it was a joke, meant to lightly tease and gently point out that nothing I had said was all that unique. Who does not, after all, want to be humane, flexible, and committed to flourishing right now? In retrospect, that simplicity was likely essential to the appeal of the principles and maybe why they were adapted to so many contexts. When I told my wife that I was struggling to explain to a reporter why they had resonated so widely because I thought they were just common sense, she responded, "I think that's the point. People just needed a reminder."

At the same time, in talking with other colleagues and reflecting on our current situation, I do wonder if something of an "anti-syllabus" is not required. Maybe not a full-throated embrace of inhumanity and inflexibility, but some recognition of the labor required to realize the ideals I articulated and how that work falls unevenly on each of us. As one professor friend, who is an untenured woman of color who has dealt with all sorts of unseen toil and unplanned contingency over the years, told me, "Your principles sound great for a white, male, able-bodied tenured professor with strong institutional support and relative autonomy in teaching. For some of us, though, that flexibility and compassion are seen as inconsistency and weakness." In fact, when she adjusted her syllabus in light of the pandemic, my friend encountered pushback, questions, and students that flooded her email with complaints. By collapsing the distance between professor and students, in the name of humanity and accommodation, some of us receive praise while 
others have their authority challenged or their vulnerability abused. For these, the principles can feel like an increased burden; it is another bit of shadow labor for folks who have been holding that humane, flexible, personalized space for students for years at risk to their own pedagogical authority and without full recognition, fair compensation, or any real sense of whether it will help or hinder their tenure chances.

Thinking about how this moment will change our teaching going forward, I am keenly aware of that pushback. Now, as it ever should be, those of us with relative privilege in the academy and in the wider society need to be doing that work without demanding it of those for whom it only increases their labor and diminishes their security. Let us allow space, even in our ideals, for imperfection and rest. For some time now, I have been studying Jesuit history and spirituality, and I believe we should be thinking of new ways to apply the Ignatian pedagogical admonition to be people for others, focused on the cura personalis, or care of the entire individual. If we focus too narrowly on ourselves and our students, however, we may miss all the ways our colleagues, our graduate students, our staff members, and our wider communities are struggling. We may also run the risk of perpetuating a sort of individual charity that does nothing to challenge unjust systems. Some are doing and have always done too much of this work and for too long been blindfolded, spun around, and told to swing at the professional piñata: "Go, go, go and do, do, do." For these and for ourselves, we need the piñata song's reminder: "Don't lose your sense, because if you lose it, you'll lose your way." Let us go into our future teaching with a renewed commitment to hold onto our senses and find a way forward together.

Brandon Bayne is Associate Professor of Religious Studies at University of North Carolina at Chapel Hill.

\section{Valerie Cooper}

Shortly after Duke University suspended face-to-face instruction this spring in response to the coronavirus pandemic and put our classes entirely online, my next-door neighbor asked me how I was going to adapt to this new reality.

"I am going to teach louder!" I responded, laughing.

I did not mean that I would shout at my classes through Zoom or some other online vector but, rather, that I would be doing what I 
could to amplify my own and my students' humanity in what remained of the semester ahead.

It seemed to me that, as students left the complex webs of social relationships they had built on campus, a sense of social belonging and connection with peers would be one of the most important things they would be missing and mourning as they hunkered down in front of their laptops and cellphones, trying to listen to lectures in locations far from campus. I believed that it would be a mistake to try to teach students during a pandemic by ignoring their humanity and even the fear and loss that they were feeling.

As an African American, I was part of a community that was being hit hard by COVID-19 illness and death. I was determined to make sure that my classes made space for students to share their very human feelings of loss and fear. I felt that a very important part of my classes going forward would be specific efforts at community building-even if that meant building a virtual community.

Rather than pretend that the semester was just going on as usual, I made an effort to acknowledge the hard work that students were doing to continue showing up for class. I encouraged students to look out for one another and for themselves and tried to make space to acknowledge the uncertainty that many were feeling. That work of virtual community building went first because I believe that students who feel unsafe and unsure will have trouble learning or caring about learning. They lose motivation. In that context, I did everything I could to amplify our humanity even as our classroom had shrunk to the size of a laptop screen.

These days, I teach at a divinity school, but in the early years of my university career, I taught in departments of Religious Studies. My colleagues and I often debated the appropriate amount of self-disclosure in such an educational context. Certainly, proselytizing is verboten, but to what extent should a faculty member let any of his or her personal religious or theological beliefs show in the course of instruction?

Some of my colleagues argued that it was never appropriate to allow any of your personal views to show. I tended to suspect, on the other hand, that despite professors' best efforts at hiding their personal opinions, students were always able to ferret out at least some of them. Most students, after all, have spent their entire academic careers trying to find out exactly what we teachers want and giving us exactly that (and no more) in every assignment they turn in. Given that so much of student success is dependent upon their ability to figure us out, I doubted that religious studies faculty were any better at hiding who we were from students than anyone else had been. 
I believe that our students figure out who we are and what we believe pretty quickly and without a whole lot of intention or even effort. Indeed, even in the discussions with my religious studies colleagues, I suspected that it was better to be upfront about our convictions than to leave students guessing-and perhaps misconstruing - who we are and what we stand for.

Whether or not it is appropriate to disclose one's personal beliefs in religious studies contexts is a complicated, ongoing debate. As a divinity school professor, however, I am convinced that emotionally distanced teaching is completely inappropriate in the context of a national and social emergency such as this pandemic. By discussing who I am, how the pandemic was making me feel, and by allowing space for my students to do so, also, I believe that I not only amplified my own humanity (despite the humanity-diminishing tendencies of technology) but also, paradoxically, made my virtual classroom a safer space for students who were suddenly feeling unsafe in the world.

\section{What Womanist Theology Taught Me}

I identify as a womanist scholar. Womanists, like black theologians and many others, reject the idea that anyone can be objective. The myth of objectivity too frequently allows those such as whites, men, and others who wield social, economic, or political power to speak as though their experience is universal and to mask their true, vested interests. Pretending that a particular white person's or a particular male's experience is somehow universal, or even objective, mutes the voices of others who do not share that experience.

Frequently, womanists begin their scholarship with an introduction, identifying themselves, their social locations, and their ideological commitments. This allows readers to interrogate the scholar's arguments with an eye toward the scholar's own commitments and potential blind spots as well. This seems to me to be a much more honest approach. Rather than pretending to be objective while hiding one's particularity, or denying holding any social or political commitments, womanists disclose theirs and invite the reader to admit that everyone has them.

Moreover, as a black Christian woman teaching at a predominantly white, Christian divinity school, acknowledging my social location means delineating it from that of other Christians who might share my faith but not my life story. It allows me to demonstrate diversity even as we acknowledge how much we have 
in common. Real community requires that I be allowed to tell my story just as you be allowed to tell yours.

Part of my commitment to amplifying my humanity during the pandemic involved being honest with students about how unsettled I was feeling. It meant admitting that the course would feel and flow differently and that some elements might not translate well in the virtual environment. It meant reminding students of my instructional goals while having an honest discussion with them about those things I already knew I could not do well, such as being able to handle some of the technologies upon which we were now dependent. Part of my commitment to amplifying my humanity during the pandemic meant showing part of myself that I might not otherwise want to reveal. It meant allowing students to see my anxiety about how my teaching might be diminished in its online presentation. It meant inviting my students into deliberations about how our class would go forward in its new reality.

\section{What Seventh-Graders Taught Me}

I became convinced very early in my career that it is important for students to know something about their teachers. Before I taught at the college level, I taught junior high school. And, yes, much of what I learned from teaching junior high school remains relevant to my teaching today.

In order to be certified to teach in a junior high, I had to take courses in course design, lesson planning, and adolescent psychology as well as content-specific courses. Those courses taught me how much my ability to teach depends upon my ability to connect with my students.

I still believe that teaching junior high school is some of the toughest teaching out there. I am convinced that it was then that I learned how to really teach. In my experience, content is always important to teaching: you must give your students information in a format that they can understand, retain, and be able to use appropriately. The younger the learner is, however, the more important it is to provide them with motivation and discipline to keep them on task in the learning enterprise. As a junior high school teacher, in addition to teaching students content accurately and competently, an essential part of my job was to provide students with the motivation to do the work. I suspect that every parent of an adolescent out there knows that one thing junior high schoolers sometimes lack is motivation!

By the graduate and postgraduate level, most students can provide their own motivation for most tasks. That is not as true of 
junior high school students, who can, at times, hate school, hate their parents, hate their fellow students, and, especially, hate themselves and their rapidly changing bodies. In such a turbulent context, something more than flawless content delivery was required. In teaching junior high school students, I learned how important it is that $\mathrm{I}$, as a teacher, make a personal connection with my students. They were more likely to be able to work hard in spite of everything else that was going on in their lives if they believed that they were part of a community that cared about them, being led by a teacher who cared about them.

As a new junior high school teacher, I studied the successful veterans. I learned that they did not try to hide their love of the subject they taught or their care for the students they were teaching. Motivating students involved making those kinds of personal connections. It meant that my classroom bulletin boards did not just display content from the curriculum but also included issues I loved from my discipline and that I hoped my students would also find interesting. It meant that I gave students opportunities to link what we were learning to what they were experiencing in their lives outside of school. I came to understand that things that helped my students connect school to their lived experiences also helped them learn.

One wonderful thing about teaching junior high school students-and, particularly, seventh graders-is that it is one of the last times in their lives when students will be completely honest about how they are feeling. They have not yet learned to mask their emotions in order to appear more cool or more pulled together. They will just blurt out their hurts, their fears, and, yes, they will rat one another out if you are looking for the culprit in a particular petty crime. In that, they made my job easier as a teacher. By college, however, students have long since learned to limit their self-disclosure and to maintain a competent air even when they are struggling. That makes it harder to recognize when students are in trouble.

Even if they were unable or unwilling to admit it, it did not take genius to realize that many of my graduate students were struggling as a result of the pandemic and the social, economic, and political disturbances that came in the pandemic's wake. Zoom and other online venues made it easier to see class differences in students' homes in a way that dorm rooms never revealed. Just as I had, some students had seen family members or friends fall ill and even die as a result of COVID-19. Those who had worked on campus had lost their jobs and income, and many had returned to homes where their parents or guardians had also lost their jobs and income. 
In addition to worrying about completing assignments, some students were now struggling with food insecurity and fearing homelessness.

For many students, the pandemic had brought an unprecedented level of instability and insecurity into their lives. Although I didn't experience much of it, I heard from faculty colleagues who saw higher than usual levels of missed assignments, incomplete assignments, and even cheating among their students. It was obvious that many students were struggling and some were failing.

None of that meant that students had reverted to adolescence but, rather, that their usual adult coping mechanisms were being strained in this new, COVID-19 context. Amplifying humanity did not mean treating them like junior high school students, but, rather, it did mean acknowledging that strain. It meant that I had to be intentional in replacing some aspects of the communities they had built on campus but had had to leave behind.

\section{Community-Building as Pedagogical Method}

How then did I "teach louder"? I began every class with a check-in on students. I would model the sort of honest disclosure I expected by admitting how the pandemic had destabilized my life. (By going first, and modeling how I hoped that these disclosures would go, I also modeled the nature of the disclosures. I kept my comments relatively short and professional; I never gave any more information than would be appropriate. This was sharing, not therapy.) Then I would call on students to talk about how they were doing.

Because I teach at a divinity school, I invited students to pray about their concerns corporately once they had articulated them. (We also prayed for concerns students had preferred not to share openly. We made intentional space for that.) I asked them specifically what they were doing to take care of themselves and lower their stress levels. We would sometimes brainstorm about activities that were safe to do in a pandemic, but also helped lower stress, such as taking a walk outside or calling a friend. I repeated important class details because I knew that it was harder for students to pay attention online than it had been in person. I put very important class details in writing but realized that students were being bombarded with emails and that they might not attend to them all very closely.

Of all the small things I did, such as giving students the opportunity to speak about themselves (rather than all the opportunities I usually give them to speak about the curricular content we present in any given class), I gave them permission to be 
human and to acknowledge and care for their humanity in a difficult time. Although they were less likely than my old seventh graders to admit that they were having difficulties, it was not hard to figure out that they were. I know I was.

At the end of the semester, I learned that I had been honored by Duke University as the recipient of an Abele Award for graduate student mentoring ("Mary Lou Williams Honors Students, Faculty and Staff with Abele Honors," Duke Today, May 8, 2020, https://today.duke. edu/2020/05/mary-lou-williams-honors-students-faculty-and-staff-abelehonors?fbclid=IwAR16rh8t145sJYc4zn2bADddNgd-OcT9vUHmpag6y 3yL36JRZ8CKqTJddxk). I was pleased that the university had recognized and approved of the work that I had done to amplify the humanity of my students.

As so many of us shelter behind literal masks for protection against COVID-19, I was glad that I had lowered my metaphorical mask to my students. The metaphorical mask that so many of us have worn since junior high school—the one that says that I am fine even when I am not-was intentionally lowered, and I allowed my students to lower theirs as well. In my classes this semester, the first work was revealing, amplifying, and sharing our humanity so that we might create a space safe enough for learning to take place. Then, once the virtual space had become a safe space for human beings to occupy, we could do the work of learning together, as a virtual community bounded together by our interest in the subject matter and by our interest in and care for one another.

Valerie Cooper is Associate Professor of Religion \& Society, and Black Church Studies at Duke Divinity School.

\section{Gastón Espinosa}

Spring 2020 seemed to unleash the wrath of God and the outrage of humanity. The meteoric impact of COVID-19 across America and around the world appeared to usher in an epidemiological apocalypse. Within weeks, the world was brought to a screeching halt-empty streets, disheveled supermarket shelves picked dry, gun stores barren. Like a trailer for The Walking Dead, the pandemic and the ensuing panic created a bunker mentality where people from all walks of life prepared for the end of the world as they knew it. More chillingly, the hopes and dreams of the next generation of students were dashed on the rocks of uncertainty and fear. Anticipating the foreboding apocalypse, colleges and 
universities across the nation sent students home to prepare for the worst as the nation waited for the pandemic to steal away upward of 2.2 million victims.

At home, families struggled to prepare for the unknown, huddled in front of screens announcing the latest death tolls. Hardest hit are the dead, sick, and the estimated more than twenty million Americans who lost their jobs or were placed on unpaid furlough. The financial disaster had a disproportionately negative impact on the most vulnerable: poorly paid racial-ethnic and disadvantaged families and students. Shut up in their homes and neighborhoods by the state-mandated stay-at-home orders, they still felt a strong, even desperate, desire to find work to buy scarce provisions. The COVID-19 crisis put sharp pressure on low-income, jobless, and furloughed families and students that, at times, seemed to overwhelm their sensory faculties. Even the brightest students struggled to stay focused on their studies.

Just when rays of hope seemed to break through fear and news that social distancing was taking effect, a second meteoric disaster hit. Like the first, it was also human-made. In the live-stream slaying of George Floyd, students saw the same ruling powers and structural system at work that had kept them from jobs badly needed for survival. The tragedy that unfolded on national television seems to disturbingly mirror the social conditions of many minorities and many others whose consciousness about inequality had been heightened by the quarantines. The pent-up frustration and mental angst of a nation strained to the brink over COVID-19 now converged with centuries of racial injustice, erupting into a fireball of masked rioters chanting George Floyd's name, with some torching cities, and demanding an end to the world of racial oppression as they knew it.

The prophetic outcries over these two human-made disasters by the same ruling powers sparked a revelation and, in some quarters, a revolution that may bring about long-term structural and catalytic change to the laissez-faire complacency in the United States and around the world. In fact, any discussion about the impact of COVID-19 on the future of American society and teaching must intersect with the riots and student protests sweeping the nation today because the two are inextricably linked, and the protestors know it. As Martin Luther King, Jr., prophetically wrote behind iron bars in a Birmingham jail, "All men are caught in an inescapable network of mutuality, tied in a single garment of destiny. Whatever affects one directly, affects all indirectly. I can never be what I ought to be until you are what you ought to be, and you can never be what 
you ought to be until I am what I ought to be.... This is the interrelated structure of reality."

Students across the nation understood the profound interrelatedness of ordinary lives with George Floyd's death in middle America, and this is precisely why tens of thousands of students and people from all walks of life flooded into the streets, marched, and protested the cruel death of an unarmed black man under the heel of white society.

Indeed, George Floyd died for our sins: the sins of our soiled past shaped by slavery, racism, and centuries of unanswered discrimination along with their ongoing legacy today. His death has taken on cosmic and symbolic, though not yet redemptive, proportions and has unleashed a whirlwind of peaceful marches but also--in the hands of opportunistic spirits--violence, looting, and bloodshed. The violence has, ironically, cut against the spirit of the original protests and hurt the very communities and minority-owned businesses that Black Lives Matter and others have worked so hard to defend. From the arc of history, the world is on fire and trenchantly portrayed on nightly television and social media. While this description might seem like hyperbole, for some, the world is on fire and some things will never be the same-and they ought not to be.

These two crises have underscored the importance of religion in U.S. society, with many clergy and religious traditions leading the call for an end to racial injustice. The COVID-19 apocalypse has underscored the continuing salience of religion and prompted Black Americans and others to turn to religion for hope. A 2018 Gallup Poll survey found that 72 percent of Americans reported that religion is important in their lives, and, in an April 1, 2020 survey, 80 percent of Blacks and Evangelicals, 65 percent of Catholics, and 55 percent of Americans nationwide reported praying for an end to the spread of COVID-19. Perhaps this should not be surprising because almost all survey research indicates that working-class, poor, and marginalized people-Blacks, Latinos, Koreans, Filipinos, and other minorities, as well as women, poor whites, immigrants, and the disabled-are disproportionately religious compared to the middle-class white U.S. population. Why Blacks and others might turn to their faith to find hope and an end to racial injustice could lead to rich discussions about the intersection among religion, race, economics, and political empowerment and social change.

\section{Identifying Underlying Problems of Inequality in Online Higher Education}

How should higher education in general and the field of religious studies in particular respond to these apocalyptic and racial 
injustice pandemics? After examining the impact of the COVID-19 pandemic in the move to online education, I will reflect on what colleges, departments of religion, and faculty can do to redeem and transform these two tragic events into learning opportunities that can help transform American higher education. In many wayssome of them ironic - the frustration on the part of racial-ethnic minorities and other disadvantaged students in wake of the COVID-19 pandemic served as a primer that set the stage for the protests that have erupted in the American psyche. Rather than discuss this situation in the abstract, I plan to write from my own experiences as a religious studies professor who teaches classes on religion, race-ethnicity, and social change. Though the college is well resourced, a growing number of its students are not.

Right after students were returned home in the wake of the apocalyptic prognosis about the impact COVID-19 would unleash on the American people, faculty were made immediately aware of the fact that not all was well with an overlooked segment of students. While many upper- and middle-class students from all racial-ethnic backgrounds were making the at-home adjustment well because of the support and resources that their families could provide, other students from broken and under-resourced families were suffering in the shadows. These students-among the most academically successful in our classes prior to the pandemic-had such sheer grit and determination to succeed that they chose not to complain about the resource inequalities they faced at home. While everyone struggled to adjust and work through the general malaise that seemed to weigh down the end of the semester, their struggles and difficulties were immediately more acute and weighty. After stoically trying to push through their limitations, many lamented privately in and outside of office hours that they were really struggling behind the scenes at home to perform at the same level of excellence they had on campus in Claremont.

At first glance it appeared that going to 100 percent online teaching might level the playing field because everyone could go home to their supportive families to get their work done. This perception, however, falsely assumed that all families had the necessary material, financial, and other resources to make the transition smoothly and successfully. It seemed to overlook that, in reality, many underemployed racial-ethnic and other disadvantaged families and students from inner-city and marginalized communities face tragic structural inequality and a lack of resources. Reports emerged about students in tears saying the pandemic lockdown made it almost impossible to concentrate and get any work done and 
that it was almost unbearable to live at home due to financial stress that resulted in parental and sibling conflict, yelling, and shouting.

What economic, class, and racial-ethnic factors placed minorities and other disadvantaged students at risk of underperforming? The state- and city-mandated stay-at-home orders across the nation forced restaurants, stores, and companies to close shop and either lay off their workers or place them on unpaid furlough. The resulting unemployment disproportionately affected Blacks, Latinx, and other poor and working-class families and students. Reports emerged about students missing class; when contacted, one student explained that their parents had been evicted from their home due to losing their jobs, and now were homeless and looking for a temporary shelter. These students had no place or time to work, let alone read, research, and find the time to concentrate enough on their readings to wade through the sources to write a thoughtful and engaging essay. Still other students reportedly shared with tears streaming down their faces that there was so much yelling and screaming going on in their small home due to unemployment and other medical issues that they could not concentrate at all during waking hours. They were forced to work, bleary eyed, from 1 A.M. to 6 A.M., which disrupted their sleep patterns and ability to function. Many other students had similar stories. Still others reported that their families could not afford the internet upgrade needed to participate in online Zoom classes and, in some cases, that their computers at home were so old they did not have working cameras and microphones and the computers often froze during online classes. This reality made completing some of even the most basic assignments exceedingly difficult. Finally, not having access to city libraries or places to buy computer and online media equipment, along with living in some of the most dangerous and drug-filled neighborhoods in urban America, made trying to track down research via books and periodicals difficult and even dangerous. These factors led to frustration, despair, and a gnawing fear of failure. More damaging to the spirits of these students, circumstances reinforced negative stereotypes that they did not belong at the Claremont Colleges as much as their well-off peers.

On top of all of these familial and academic resource problems, in the admittedly chaotic transition returning home, some reported having difficulties, confusion, or delays in navigating or accessing key social services such as free peer-tutoring, the counseling center, racial-ethnic student affairs, and the religious chaplaincy center, which had helped many address the anxieties they faced in previous semesters. Through no fault of anyone or anything other than the impact of the pandemic, they lost direct in-person on-campus access 
to the communal support networks and people that had provided critical support. Here, they could find supportive peers and professionals and scarce resources. While these resources went immediately online to continue providing excellent care, the return home and loss of in-person meetings due to the state-mandated stay-at-home orders undercut students' ability to reach them. This lack of physical access contributed to a growing social distance from their educational experience and to a sense of isolation, which undercut their resolve to struggle through the pandemic amid the cascading crises it seemed to engender. The loss of these critical social services along with a reduction or, in some cases, a lack of regular interaction with their professors, students, staff, and guest speakers undermined their overall intellectual stimulation and engagement in the classroom. Having to watch prerecorded lectures made it difficult for students that come from relational and oral cultures to engage the material in the same way they had done in class with its more relational interaction. In short, many students painfully struggled to perform at the same level of excellence they had prior to the pandemic due to the absence of direct, interpersonal on-campus teaching relationships with their professors and peers and the practical loss (from their vantage point at home) of the intellectual free space, dorm rooms, library resources and quiet study spaces, and professional support and social services they needed to excel, despite the fact that all were at varying levels still fully operational and eager to help, but only in online formats. The shame that many students felt for seeking help because it reinforced the perception that they did not belong was, perhaps, the greatest pandemic of all.

If these academic difficulties were not enough, they also faced pressure from their families at home to find work and somehow contribute to their households. Many spent time looking for work and still others were forced back into unhealthy family dynamics and living arrangements, all the while feeling pressure to excel in the classroom. Research in economics and other fields has shown that racial-ethnic minorities-especially Blacks and Latinx-and other disadvantaged youth (some other immigrants, poor whites, and others) have much higher poverty and underemployment rates and tend to live in poorer and under-resourced communities than those in the rest of America. In short, their socio-racial-economic location placed many racial-ethnic minorities and other disadvantaged youth at greater risk of underperforming and failure than the general U.S. population.

While middle- and upper-class students and their families could mitigate and better deal with some of these factors because 
they had the resources and the extra living space to do so, other students were not so lucky, and they found themselves in a crisis and facing various difficulties at home. This situation created something of an educational apocalypse for racial-ethnic and under-resourced students wherein their academic worlds and hopes and dreams for a better life were seemingly dashed on bitter rocksbut with a sharper mercilessness than for most other students. The result was frustration and anger for some and resignation for others. In short, the COVID-19 apocalypse laid bare the structural inequality these students faced and revealed why they were being placed in a position where they were almost predestined to underperform. While most boldly made it through the process, others, I am sad to report, did not.

\section{College and Student Responses to the COVID-19 Pandemic}

How did the college and faculty respond to the COVID-19 pandemic? The college tried to make sure students had a functioning computer. It also provided a one-time payment for transportation home, for increased internet bandwidth for the remaining two months of class, for inexpensive but functional cameras if their computers did not have one so they could participate in online classes and online counseling, and for many other resources. They also worked to make some of the past social services available via Zoom or telephone. Some students were given the freedom to stay on campus if they were international, homeless, or faced an unsafe or abusive home environment. Faculty sought to address these deficiencies by offering students additional office hours and counseling to discuss their work and struggles; assigning new, modified, and shorter readings and papers; creating breakout and chat rooms; providing tutorials and prerecorded lectures students could watch in their own time-zones; reducing three-hour classes to just two hours; and trying to connect the origins, impact, repercussions, and implications of the pandemic to what they were studying. Perhaps, more importantly, some faculty brought these issues to the attention of the administration in order to find larger structural ways to support and enable students to push through the crisis.

Despite these initial faculty efforts in March and April, students and faculty immediately saw the disparity and structural inequality for students who came from underemployed racial-ethnic minority and other disadvantaged backgrounds. As a result, about twenty percent of students banded together to create a petition that asked the college to, among other things, modify the grading scale 
for spring 2020. Students from the other four colleges generated similar petitions. The main argument was that students from racial-ethnic minority and disadvantaged backgrounds would be indirectly penalized and set up to underperform because they went back to homes without the space, resources, and stable working environment they needed to excel. While not conceding to all of the student requests, the college took what it believed to be a middle-ground position: allowing students the choice after they saw their final grade to either keep their letter grade or to change their letter grade to credit/no credit. Faculty could not override the student's choice. The rationale was that students who had underperformed due to factors related to the COVID-19 pandemic - perhaps confidential factors that the student did not feel at liberty to share with their teacher or college for many reasons-would now have the option of taking courses for credit without it adversely affecting their grade point average and, hence, their future job and graduate school applications.

Many racial-ethnic and other disadvantaged students, faculty, and their allies, however, were frustrated by this course of action. They felt that it would invariably privilege students with greater resources and force students without them to have to take the course only for credit instead of a letter grade, not due to lack of effort or ability but, rather, because of a lack of resources and a stable learning environment-factors completely out of their hands. Students proposed instead that the college follow the grading policy of other colleges and universities by requiring all students take a universal pass (no letter grades for anyone) or no record pandemic/ incomplete, thus ensuring that there would be equity for all in the grading system. No one single group would benefit because they had access to greater resources and support.

Not all students, including some from working class and/or racial-ethnic minority backgrounds, agreed with this universal pass proposal, and they mobilized against it. They claimed they were being forced to accept an unfair grading policy that, in their view, would actually harm their future applications and work prospects in general. Seniors, they argued, would be particularly impacted because this semester would be their last chance to increase their overall and major GPAs before graduation. After extensive and energetic discussions, the college ultimately sided with the second group of students, though modifying their grading policy further to state that any course grade of D- or better could receive credit in lieu of their final grade. To further close the gap in students' socioeconomic advantages, the college encouraged the faculty to take into account the difficulties of the COVID-19 semester when assessing final grades. Needless to say, the students petitioning for 
universal pass were frustrated by what they perceived as the structural inequality that shaped both the school's policy and the larger society that made it more difficult for them and their families to succeed.

All of this conflict over grading spotlighted the racial and class disparities and inequality in American higher education. It also revealed-perhaps like never before-the deficiencies of online education and provided tangible grounds to counter the argument that online education and assessment is largely race and class neutral. This inequality, which had hitherto been seen largely by only those students suffering from it and by supportive faculty and staff working behind the scenes to mitigate it, was now publicly exposed for the entire college to see, perhaps for the first time in such a clear and compelling way. Racial-ethnic and other disadvantaged students ended the semester frustrated and, in some cases, angry about the structural inequality of not only online education but also the college's inability to address the issue in a way that leveled the playing field and benefitted the entire student body, not just those with resources. They interpreted the problem as racial in kind because they knew that most of the students who came from racial-ethnic minority backgrounds also correspondingly came from poor, working-class, and underemployed families, including many with single parents, who were unable to match the resources of middle and upper class families.

\section{COVID-19 Apocalypse and George Floyd Riots: The End of the World as We Know it}

The growing frustration with the COVID-19 educational apocalypse, in many ways, helped set the stage for the future student revolts, protest marches, and riots that swept the nation in the aftermath of Floyd's tragic death. Students saw the intersectional link between their academic scenario, which put them at a clear disadvantage and in a position to underperform, and the killing of George Floyd, which was caused by the systemic injustice that his death came to signify in the media aftermath. Both the students and Floyd had one thing in common: their working-class racial-ethnic heritage resulted in differential resources, treatment, and outcomes in a larger structural system, higher education in one case and the legal system in the other, that did little to mitigate their vulnerability. The fact that Floyd's death happened right after most students had just finished a frustrating and disappointing spring semester in American higher education, primed the pump for a release-nay, revolt-against the institutional forces they believed did not listen to their cries for freedom, equity, and justice. They were not alone. 
Students who were given a universal pass and those who were not both had their consciousness awakened. Despite its purported liberal framework, higher education seemed complicit with a system that invariably favored the powerful. The students' institutions did notand, perhaps, could not, from their own point of view so late in the semester-adequately correct the imbalance to level the playing field. These students and those who sympathized with them were ready to seek a remedy.

The absolute abuse of power that led to Floyd's death was the match that set the country and world on fire. The state-mandated COVID-19 lockdown (ironically, most strictly enforced in Democrat-controlled urban areas, including many with high poverty and unemployment rates) along with the student and faculty frustrations over the racial-ethnic structural inequality, resonated deeply with the same frustrated voices that cried out for justice and demanded to be heard in the wake of the Floyd's death. The largely student-staffed Black Lives Matter movement provided a vehicle and forum through which people could express pent-up feelings, anger, and execute a searing search for justice. Now, just out of school, students took to the streets and joined countless others from all walks of life to demand justice in the wake of the two human-made apocalypses they were hitherto forced to watch but not protest.

No more. They rushed pell-mell into the fray, though not always with ordered discipline, a clear leader, or a set of objectives. Like a tornado, they ripped through America's downtowns and, sadly, inner cities, leaving some of the very places that were already on edge and underserved devastated by outside agitators, who burned, looted, and destroyed big chain stores as well as small, minority-owned businesses, social service agencies, and the already decaying infrastructure that they depended on for survival. The movement to call out violence and restore justice was hijacked by largely white, middle-class, masked, and hooded anarchist groups like Antifa, whose followers infiltrated the protests to unleash mayhem not just on the rich but also, invariably, on the poor by setting fire to and destroying the infrastructure and resources in their neighborhoods. Still others assassinated black police officers protecting city hall and other civic buildings. A few racial-ethnic minorities from the community created their own mayhem, while others followed Antifa's lead. While Black Lives Matters, black Christian clergy, and community leaders attempted to correct this take-over, the damage has already been done. The redemptive orientation of many protesters, along with calls for major reform, were replaced on the nightly news by images of fire, shootings, and violence. In one YouTube post that went viral, a group of 
Antifa-styled, white-masked and hooded college-age students are shown setting parts of a poor racial-ethnic community on fire. A brave black woman-despite being surrounded by over half a dozen white masked and hooded anarchists-shouted down what they were doing and told them to go back to uptown and register to vote. She shouted, "These are. . . people who live in public housing! And you just made a melee. . . . You are here profiting off our pain. ... You come in here with your $\mathrm{f}^{*}$ cking privilege and take down resources that my community needs. . . . Stay out of our neighborhoods." Rather than stop, they continued to burn what they never cared to know or lift up.

Responding to Educational Inequality in the Shadow of COVID-19 and George Floyd Crises

How can we transform the meteoric impacts of the COVID-19 pandemic and George Floyd protests and riots for racial justice into teaching moments and best practices about how and what we will teach in the future? First, the way we will teach in the future has been forever changed by COVID-19 because almost all faculty across the United States and around the world have been forced to teach online for the first time in the history of the world. In fact, it is a shared generational, paradigmatic "I was there" moment. More than that, it is the birth of a new renaissance in teaching pedagogy that has moved from a largely in-person spatial experience in the classroom to an in-person online virtual experience over the internet. Fundamental questions about faculty-student engagement, communication, content, and delivery will be forever changed because now faculty the world over have learned how to teach online. Whether this will be a permanent transformation for all faculty or a temporary blip on the screen is unclear. Online teaching has both extended the repertoire of pedagogical tools for teachers and possibly undercut (or, from another perspective, underscored) the value of in-person, on-campus teaching. What was once the platform, approach, and pedagogy of for-profit colleges and programs across the nation has now become mainstreamed and acceptable.

Second, faculty have been forced to find ways to use technology to engage students in new, innovative, and more meaningful ways. Students who once listened to live lectures in class are not willing to spend their time listening to live lectures online. Most are putting pressure on faculty to simply prerecord the lectures so they can watch them at their leisure and then either test them on the material and be done with it (a more transactional and 
consumer-driven approach) or hold a meaningful online discussion about the material (a more transformational and experientially driven approach). In the second attitude, we see how the move to online teaching has prompted students to demand more existential value and intellectual engagement and stimulation out of their educational experience. They want to know what this means for them and their world today.

Third, faculty are having to use more engaging pedagogical approaches to teaching, such as chat rooms, break-out groups, Facebook postings, YouTube postings, the creation of classroom interactive websites, teaching modules, and break-out group debates. The apocalyptic and racially charged experiences of 2020 are forcing faculty to ask questions that go into the deeper meaning and existential significance of the topic.

Fourth, in my own classes, I have created a carefully selected collection of primary source readings and set of highly focused questions (definitional, thesis/theory/evidential, explanative/ interpretive) that force the students to identify the main thesis, theory, or point of the reading, tie it back into the larger theme of the course, and then reflect on its overall significance in society today. Our goal is not simply to identify the main reading topic and then assess it but also to understand its contribution (positively or negatively) to the larger culture. These questions also help guide the student reading, pointing them to what's really important. Moving beyond mere facts and dates, they walk away with a clear understanding of the terms, definitions, main thesis, theory, argument, evidence for the argument, and their own reflections on what they have just learned and how it intersects with profound issues in our day. I found that approach worked well online because giving the students the questions at the beginning of the semester for all of the class units meant that they could take their time to work through the reading and on the paper as far in advance as they wanted-though most just waited until the night before! My larger point is that the move to online education provides faculty an opportunity to find more engaging ways to foster critical thinking and analyses of the material that offers some existential value and new frameworks for interpreting contemporary life.

Finally, as we saw earlier in this essay, online education has forever spotlighted the inequality and structural problems some students from racial-ethnic minorities and other disadvantaged backgrounds face in the academy. In a real sense, it underscores one of the main values of returning to in-person, in-classroom teaching on campus; if all of the students live on campus and have access to the same resources, then they should have a more similar chance of 
performing at the same level as their peers. Still, as we all know, students who come from inner-city or under-resourced public and private schools may not have had access to the same quality of college-prep teaching, training, and learning as those students who attended highly elite private schools. In all of these ways and in many others, the COVID-19 pandemic has permanently changed not only how we think about teaching online but also its relationship to higher education and the equity and disparities involved in that education.

Now, we should ask how the COVID-19 pandemic and the George Floyd protests for racial justice have each challenged and changed what we teach and why we teach it. The pandemics and protests have given faculty a platform and an opportunity to spotlight and address a number of key themes in religious studies and American society, such as race, class, discrimination, white supremacy, colonialism, economic injustice, structural inequality, justice, hope, fear, redemption, activism, social change, politics, power structures, globalization, biological warfare, violence, futurism, apocalypticism, and a vast array of others. This COVID-19 crisis has created a natural opportunity to discuss the intersection among religion, apocalyptic events, racial strife, struggles for justice, economics, and political disenfranchisement and empowerment.

While the COVID-19 pandemic will pass and invariably have a modest but important impact on how we go about teaching in the future, the George Floyd racial justice protests could have a much more profound impact on what we teach and how we might respond to the antiblack crisis that this second meteoric pandemic seems to have underscored. Our college responded by launching the CMC Presidential Initiative on Anti-Racism and the Black Experience in America. It called on faculty, students, and staff to reflect and act on strategies for addressing racism, anti-blackness, and racial-ethnic marginalization at the college and in society. How might religious studies departments and scholars respond on an institutional, departmental, and personal level to similar initiatives in American society and higher education? Some of the possible steps that our department discussed included:

- acknowledging the suffering of the black community and our complicity

- listening carefully to the struggles of black and racial-ethnic minority people

- hiring faculty in departments such as religion, history, politics, and economics where they can naturally teach 
about racism and civil rights and the black experience in the United States and Africa

- creating new courses that address racism, antiblackness, and discrimination

- creating university policies that promote and ensure racial-ethnic equality for all

- addressing inequalities in our educational system (for example, in online classes and grading)

- sponsoring speakers and seminars about antiblackness and racism more broadly

- funding internships and leadership programs for black and racial-ethnic students

- creating new awards, prizes, and scholarships in racial-ethnic studies (for example, best thesis)

- creating new religious studies tracks and majors dealing with race-ethnicity

- bringing racial-ethnic alums to campus to talk about life and keeping community ties

- continuing to mentor racial-ethnic minority alums after graduation

- creating student-student tutorial programs with college and high school students

- creating faculty-student research assistant programs during the school year and summer

- creating five- and ten-year plans for diversifying the faculty and curriculum

Finally, faculty can reflect together on how they might reach out to and recruit black and other racial-ethnic minority students, faculty, and staff in light of this new programming and, by so doing, contribute to a renaissance and intellectual transformation in the lives of their students and college. All these steps can redeem these two apocalyptic moments into a transformational web of mutuality that helps remake the world as we know it into what it ought to be.

Gastón Espinosa is Arthur V. Stoughton Professor of Religious Studies at Claremont McKenna College. 